\begin{tabular}{|c|c|c|c|c|c|c|c|}
\hline \multicolumn{8}{|c|}{$\mathrm{APE}$} \\
\hline & $\begin{array}{c}\text { Goril- } \\
\text { las }\end{array}$ & $\begin{array}{c}\text { Chim- } \\
\text { panzees }\end{array}$ & Orangs & $\begin{array}{c}6 \\
\text { Gib- } \\
\text { bons }\end{array}$ & $\begin{array}{c}2 \\
\text { Ba. } \\
\text { bo ons }\end{array}$ & $\begin{array}{c}3 \\
\text { Ma- } \\
\text { caques }\end{array}$ & $\begin{array}{l}\mathrm{x} \\
\text { Colo- } \\
\text { bus }\end{array}$ \\
\hline $\begin{array}{c}\text { Five lower } \\
\text { true } \\
\text { vertebræ }\end{array}$ & $\begin{array}{l}115.3 \\
\text { III } 17 \\
\text { III } 3 \\
\text { IO5.3 } \\
\text { IOI } 9\end{array}$ & $\begin{array}{l}125.3 \\
1117.1 \\
116.4 \\
\text { II } 6.1 \\
115.8\end{array}$ & 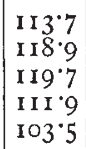 & $\begin{array}{l}\text { I I 2.8 } \\
\text { I08.8 } \\
\text { IO7.5 } \\
\text { I06. } \\
\text { I04. } 1\end{array}$ & $\begin{array}{r}117.7 \\
\text { I } 20.6 \\
\text { IO } 8 \\
\text { IO } 7.3 \\
92.8\end{array}$ & $\begin{array}{l}109^{\circ} 7 \\
\text { I07.8 } \\
103 \\
103.2 \\
96^{\circ} \cdot 2\end{array}$ & $\begin{array}{c}103.8 \\
103.8 \\
103.8 \\
108 \\
90.4\end{array}$ \\
\hline Average inde & $108 \cdot I$ & II 7.5 & I I 2.9 & $107^{\circ} 1$ & $108 \cdot 5$ & $103 \% 7$ & 1024 \\
\hline
\end{tabular}

It can be proved in many ways that the lumbar curve of the spine is more marked in the human female than in the male. The methods adopted for the elucidation of this point were : $(\mathrm{I})$ tracings of mesial sections of the frozen spines of the two sexes (2) Measurements of the anterior and posterior surface of the lumbar region; and (3) measurements of the individual Jumbar vertebræe

The difference between the indices of the vertebræ of the two sexes are not confined to Europeans, but are also observed in four of the five lower races examined, as will be seen from the following table :-

\begin{tabular}{|c|c|c|c|c|c|c|}
\hline \multirow[b]{3}{*}{$\left.\begin{array}{l}\text { Average index } \\
\text { of the five lum- } \\
\text { bar vertebræ ... }\end{array}\right\}$} & \multicolumn{2}{|c|}{ lrish } & \multicolumn{2}{|c|}{ Andamans } & \multicolumn{2}{|c|}{ Negroes } \\
\hline & $21 \delta$ & $23 \%$ & 145 & $9 ?$ & $7 \delta$ & $3 ?$ \\
\hline & $96 \cdot 2$ & 93.5 & $106 \cdot 3$ & 1024 & 106 & 103.4 \\
\hline & \multicolumn{3}{|c|}{ Australians } & \multicolumn{3}{|c|}{ Tasmanians } \\
\hline & \multicolumn{2}{|c|}{ Iot } & 49 & $2 t$ & \multicolumn{2}{|c|}{19} \\
\hline $\begin{array}{l}\text { Average index } \\
\text { of the five lum. } \\
\text { bar vertebræ.... }\end{array}$ & \multicolumn{2}{|c|}{110.1} & $103^{\prime} I$ & $108 \cdot 5$ & \multicolumn{2}{|c|}{1047} \\
\hline
\end{tabular}

It can be shown that the indices of the lumbar vertebræ of a given European spine are in strict accordance with the degree of lumbar curve. But, whilst this is the case, the difference between the anterior and posterior vertical diameters of the vertebral bodies is so slight (as Weber has observed) that it can have little effect in producing the lumbar curve. The formadaptation of the vertebral bodies must, therefore, he regarded as the consequence, and not as a cause, of the curve: at the same time it cannot be due to an immediate and mechanical influence operating upon the vertebral bodies during the life of the individual. If it were so, the same characters would be present in the lumbar vertebræ of the low races, and even of the anthropoid. It is an hereditary condition.

The European, who leads a life which rarely necessitates his forsaking the erect attitude excent as an intermittent occurrence, and then for short periods, has sacrificed in the lumbar part of the vertebral column flexilility for stability. It is evident that the deeper the bodies of the vertebræ grow in front, the more permanent, stable, and fixed the lumbar curve will become, and the more restricted will be the power of forward-bending in this region of the spine. The savage, in whose life agility and suppleness of body are of so great an account, who pursues game in a prone position, and climbs trees for fruit, \&c., preserves the anthropoid condition of vertebræ, and in consequence possesses a superior flexibility of the lumbar part of the spine.

\section{SNOW-COVERING AND THE WEATHER}

$D^{\mathrm{R}}$. WOEIKOF, who is one of the meteorologists of the modern school, has long entertained a deep conviction that meteorology ought not to limit itself to a mere observation of those few instruments which for nearly fifty years have constituted the plant of meteorological Observatories. In the development of its general laws and the application of them to forecasts of weather, it must widen the circle of its observations, and take into account those factors upon which weather and climate depend in each given locality. For the past fifteen years he has devoted his time to the study of local climates and their dependence upon local causes, such as the local deflections of the paths of cyclones and anticyclones; the proximity of seas, steppes, marshes, and forests, and the local heating and cooling of the ground. His chief work, published in Russian, entitled "The Climates of the Globe," is most valuable, on account of the wide linowledge it evinces of the various circumstances on which climate depends, especially with regard to the immense plains of Russia.

The influence of the snow on climate, of its depth and consistency, the time of its first appearance and disappearance, the evaporation from its surface, the purification of air when it has fallen, and a variety of minor circumstances, the importance of which has been insisted on by Dr. Woeik of since 1872 , are all referred to. Unhappily, observations on snow are very few and imperfect, and in a paper recently read before the Russian Geographical Society, and now printed in its Memoirs (xv, 2), he returns to the subject, illustrating the importance of such observations by a few well-chosen examples.

The year 1877 was a striking instance of how the absence of snow was accompanied by a far less notable lowering of temperature during the prevalence of anticyclones than would have been the case had the soil been covered with snow. In 1877 there was no snow in Eastern Russia until Christmas, and in November and December the anticyclones occurred, accom. panied by no wind, or only by feeble breezes. Quite bright weather lasted in December for more than ten days; and still in the region which remained uncovered with snow no great cold was experienced as usually happens in such circumstances : the minima were $8^{\circ}$ to $9^{\circ}$ above their average values. The same conditions were noticed during the winters of 1879.80 and $\mathbf{1 8 8 1}$ 82, in West Europe, as shown by Dr. Billwiller in the Zeitschrift fiir Meteorologie for 1882.

In Dr. Woeikof's opinion the relatively high mean temperature of November, as compared with March, in South-East Russia and the Kirghiz Steppe may be explained by the circumstance that in these localities the soil usually is not covered with snow in November; and thus, not being separated from the air by the snow, which is a bad conductor of heat, it rather contributes to maintain a higher temperature in the air resting on it. On the other hand, towards the end of winter the surface is much cooled and exercises a refrigerating influence on the air. Examples from the United States adduced by M. Woeikof seem also to confirm this view.

The refrigerating influence of a thick covering of snow in the spring and the influence it exercises in retarding the arrival of warm weather is so obvious that it need not be insisted on. A paper was written by M. Woeikof, in 1872 , on this sub. ject; and the very interesting illustrations he has adduced to show the refrigerating influence of a snow-covering during years when snow was abundant, are very striling. He has since returned to this subject in his "Climates of the Globe," and in the paper we mention; and we may consider it quite established that it is precisely to this agency that the relative coolness of the spring months in Russia and Siberia is due. Moreover, it may be considered as certain that when the snow-covering has been thick, and especially when the snow has a harder consistency, the arrival of warm weather will come on late in the spring.

Another result which Dr. Woeik of has established relates to the commencement of first durable frosts. As long as there is no snow, or little, he argues that frosts may begin, but they will not be durable, and the temperature may rise above the freezing-point; but it is the snow-covering, although not very thick, which gives durability to cold weather. It is easy to foresee how important it becomes, in forecasting the weather, to know, both in spring and autumn, if there are, to the north and east of any region, broad spaces covered with snow.

It is useless to insist upon the importance of an exact knowledge of the depth and consistency of the snow for forecasts in. the interests of navigation, especially in countries like Russia, where navigation on so many rivers is carried on only at high water. Several interesting illustrations of this influence are given by the author. In view of these important results, it is 
most desirable that all observations regarding snow should be made part and parcel of regular meteorological observations. The Ural Society of Naturalists has already collected valuable materials under that head, and it may be assumed that scientific and practical meteorologists will not be slow in taking advantage of such observations.

P. K.

\section{UNIVERSITY AND EDUCATIONAL INTELLIGENCE}

CAMBRIDGE.-Mr, S. F. Harmer, B.A., has been appointed Demonstrator of Animal Morphology, in the place of Mr. Walter Heape, resigned. Mr. Harmer was previously Demonstrator of Comparative Anatomy.

The subject for the Sedgwick Prize Essay in $\mathbf{1} 889$ is the Petrology of the Igneous Rocks associated with the Cambrian (Sedgwick) of Carnarvonshire. The essays must be sent in on or before October I, I888. It is open only to graduates of Cambridge who have resided sixty days during the year preceding that date.

On the 22nd inst, the General Board of Studies will proceed to nominate a University Lecturer in Geology for five years, in the place of Dr. R. D. Roberts, now Secretary to the London Association for the Extension of University Teaching.

A report of the General Board of Studies has been carried, recommending that no fees shall be paid by students to Professors and Readers in consideration of the lectures which form part of the ordinary duty of their office, but only for further assistance and material or apparatus; also that a return shall be given to the Board of lectures delivered, extra teaching given, and fees charged.

The important proposals respecting the additional subjects in the Previous Examination required of candidates for honours have been carried in such a way as to make them broader in their effects. The substitution of Mechanics for Statics was carried by 58 to 44 . The alternative of French or German was introduced by 59 to 42 ; and then, somewhat surprisingly, the restriction of this alternative to candidates for the Mathematical Tripos, and the requirement that candidates for any other tripos than the Mathematical should pass in the mathematical additional subjects, were rejected by 53 to 49 . Thus a great step in advance is made, and any candidate for honours can take Mathematics, French, or German as an additional subject.

Mr. Leslie Stephen has been reappointed an Elector to the Knightbridge Professorship, Lord Rayleigh to that of Chemistry, Mr. Christie, Astronomer-Royal, to the Plumian Professorship; Dr. Humphry has been appointed an Elector to that of Anatomy in place of the late Dr. Allen Thompson; Mr. F. Darwin has been reappointed an Elector to that of Botany ; Dr. G. J. Hinde has been appointed an Elector to the Woodwardian Professorship of Geology in place of Rev. E. Hill ; Prof. Stokes, P.R.S., has been reappointed an Elector to the Jacksonian Professorship ; Dr. H. C. Sorby, F.R.S., to that of Mineralogy; the Right Hon. G. J. Goschen, M.P., has been appointed an Elector of that of Political Economy, in place of Prof. A. Marshall ; Prof. H. N. Moseley, F.R.S., has been reappointed an Elector to that of Zoology and Comparative Anatomy; Prof. Stokes, P.R.S., to the Cavendish Professorship ; Lord Rayleigh to that of Mechanism; Dr. F. J. Farre to the Downing Professorship of Medicine; Prof. Huxley to that of Physiology; Sir James Paget to that of Pathology ; Prof. William Wallace has been appointed an Elector to that of Mental Philosophy and Logic, in place of Mr. James Ward; and Mr. Cadge to that of Surgery. The appointments in each case are for eight years.

The report recommending the institution of a Tripos Examination in Engineering, to be combined to some extent with the Natural Sciences Tripos, has been discussed at some length in the Senate. Mr. Hill thought parts of the Mathematical Tripos and the Special Examination of Engineering sufficient. Mr. Trotter throught the proposed examination was required both for engineering students and students of physics. It was desirable to increase the mathematical training of students of engineering. The Mathematical Tripos had, he thought, suffered from its long and illustrious history. The Examiners felt bound to find something new, and a good deal of students' time was spent in recognising old things in disguised forms, and in solving mathematical puzzles, not suitable for an engineering student pressed for time, or for a student of experimental physics. Prof. Stuart said he was in a position to state that the University had now the opportunity of making its engineering certificate very much ahead of anything else in the world. In one very important respect the new examination would differ from the Mathematical Tripos; it would include practical work in its earliest part.

NEw science buildings are now being erected for Tonbridge School at a cost of nearly 14,000l. They will contain chemical and physical laboratories, lecture-room, class-rooms, preparationrooms, and in addition a library and room for drawing.

\section{SCIENTIFIC SERIALS}

The Journal of the Royal Microscopical Society for December I 885 contains:- On some new and rare Desmids, by W. Barwell Turner (plates 15 and 16 ). Describes a number of new species, for the most part from the United States of America, but the localities are not always very definitely given. A new genus, Leptozosma, is made for a filamentous form near to Bambusina, Kuttz, but differing in the sutures. The various forms mentioned are all figured.-Further experiments on feeding insects with the curved or " comma" Bacillus, by Dr. R. I. Maddox. The curved Bacilli are apparently able to retain life in the intestinal tract of flies, and so might possibly become a source of injury to animals. -On the cholera "comma" Bacillus, by G. F. Dowdeswell, M.A.-On an improved form of Stephenson's binocular prisms, by C. D. Ahrens.-Remarks on Prof. Abbe's note on the proper definition of the amplifying power of a lens or lens-system, by Dr. E. Giltay.-On the limits of resolution in the microscope, by Frank Crisp, LL.B., with a note by Prof. Abbe. - The usual summary of current researches and the proceedings of the Society.-At one of the meetings Mr. Crisp exhibited a series of photographic portraits of all the Presidents of the Society. These-eighteen in number-appear in the present part, arranged on two plates of eight portraits each and two full-page portraits of $\operatorname{Sir} \mathrm{R}$. Owen, the first President of the Microscopical Society, and of Mr. Glaisher, the first President of the Royal Microscopical Society.

Wiedemann's Annalen, Bd. xxvii. No. I, January.-F. and W. Kohlrausch, the electro-chemical equivalent of silver, together with an experimental proof of the measurements of intensity of terrestrial magnetism. These determinations, chiefly by the method of Joule, appear to have been made with the utmost regard for precision in all details. The value of the electro-chemical equivalent of silver deduced is about 0.06 per cent. higher than that given by Lord Rayleigh, being o'0o I I I83 granme per ampere, as against 0.00III79. Mascart's latest value was 0.001ri56. This would make the equivalent of hydrogen $0.000010386 .-\mathrm{A}$. Kundt, on double refraction of light in metal films which are produced by disgregation of a cathode. Films deposited by electric discharges from a pointed cathode show a circularly-arranged dichroism when viewed in the polariscope.-Ch. Liideking, on the specific heats, specific gravities, and heats of hydration of the fatty acids and of their mixtures with water.-Otto Schumann, on the density of the adsorbed films of air on surfaces of glass.--J. Lahr, Grassmann's vowel-theory in the light of experiment. Discusses the results obtained by Jenkin and Ewing with a phonograph, and by Schneebeli with a phonautograph. - E. Aulinger, on the relation of Weber's theory of electrodynamics to the principle of unity of electric forces propounded by Hertz.-O. Tumlirz, on the properties of rock crystal in the magnetic field. This paper announces the discovery in this body of residual diamagnetic properties. - Eug. Blasius, notice on Japanese mirrors. Describing kindred phenomena with glass plates which have been scratched at the back with a writing diamond.-E. Lommel, aerrostatic balance for the determination of the specific gravities of gases.

Archives Italiennes de Biologie, tome vi. fasc. 3, May 30, 1885 . --This part completes volume vi. of this Archiv, and in it the editors apologise for its tardy and irregular appearance, which was caused by the terrible epidemic which afflicted Italy in $\mathbf{1 8 8 4}$. For the future the Archio will appear not at stated periods, but as matter is ready for publication, every tinree parts to form a volume. This part contains the last part of a notice of Dr. Beccari's work on "Piante Ospitatrici," by M. E. Levier. These host plants, noticed first by Rumphius in 1750, have been studied in New Guinea and in the Malay Archipelago by Beccari, the first part of whose deeply interesting account of them and their ant guests has but recently been published.- On a case of congenital cataract, by J. Albertotti. The patient was operated on at the age of $2 \mathrm{r}$. The operation 